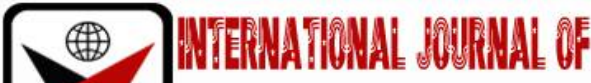

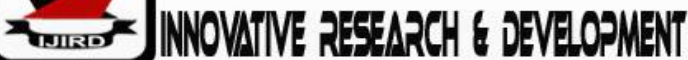

ISSN 2278 - 0211 (Online)

\section{Flood Risk Mapping and Management in Coastal Communities of Lagos State, Nigeria}

Adeniran M. A
Chief Executive Officer, GeoReal Surveys Limited, Abule Egba, Lagos, Nigeria
Igbokwe J. I
Professor, Department of Surveying and Geoinformatics,
Nnamdi Azikiwe University, Awka, Anambra State, Nigeria
Iyiola O. F
Principal Lecturer, Department of Surveying and Geoinformatics,
Federal School of Surveying, Oyo, Oyo State, Nigeria
Effiong E
Chief Lecturer, Department of Geographic Information System,
Federal School of Surveying, Oyo, Oyo State, Nigeria
Ajani A. O
Senior Lecturer, Department of Geographic Information System,
Federal School of Surveying, Oyo, Oyo State, Nigeria

\begin{abstract}
:
Coastal cities in African urban areas have high concentration of residential, industrial, commercial, military and educational facilities. The Nigerian coast is likely to experience severe effects from flooding which is due to low elevation and topography especially at high tides during rainy season. This study examined the factors responsible for flooding in Lagos State and its impacts in terms of social, economic and environmental consequences. The methodology for the study included downloading Landsat 7 image and classification in ArcGIS software using supervised image classification methods. This assisted in the identification of human activities contributing to flooding in the study area. Elevation data was obtained from SRTM data downloaded in earth explorer (http://earthexplorer.usgs.gov/), Digital Elevation Model (DEM), slope, aspect, river network, etc. were extracted. Slope, DEM and classified Landsat 7 image were further processed to identify areas vulnerable to flooding in the study area. The effects of flooding were clearly stated and recommendations made.
\end{abstract}

Keywords: Flooding, Digital Elevation Model (DEM), vulnerability, image classification, Geographic Information System (GIS)

\section{Introduction}

Coastal areas represent the transition zone between sea and land, a significant percentage of the world population live a short distance from the coastal line because of economic activities which are related to tourism. Coastal areas are vulnerable to some hazards such as floods, storms and erosion (Antonella et al, 2018). Flooding can be described as weather-related hazard that is most widespread around the globe which can occur virtually anywhere. A flood is water overflowing onto land that usually is dry. Flooding is often thought of as a result of heavy rainfall, but floods can arise in a number of ways that are not directly related to on-going weather events. Acomplete description of flooding must include processes that may have little or nothing to do with meteorological events. Nevertheless, in some cases, the water that is involved in flooding has fallen as precipitation at some time, perhaps long time ago. Floods produce damage through the immense power of moving water and through the deposition of dirt and debris when floodwaters finally recede. The effect of flooding can be devastating on structures and on the objects within them: books, furniture, photographs, electronic equipment, and soon can be damaged simply by being immersed in water. Floodwaters typically contain suspended silt and potentially toxic microorganisms and dissolved chemicals. This means that floods usually compromise drinking water supplies, resulting in short-term shortages of potable water, with the additional long-term costs in restoring drinking water service to the residents of a flooded area. The mud and debris left behind when floodwaters recede can be costly to clean up and also represent a health hazard, especially when there are decomposing bodies of drowned wild and domestic animals in the debris (Dosewell, 2003).

Coastline in Nigeria is about $850 \mathrm{Km}$ and the country's coast is divided into four units namely: the Niger Delta, the mud coast, the Strand coast and the Barrier Lagoon coast. The Barrier Lagoon coast is made up of a number of islands, 
lagoons and creeks including Lagos Island, Ikoyi Island, Victoria Island, Lekki and Lagos lagoons, Badagry and Badagry creeks. The Lagos Islands are very low lying with terrain heights between $1.5 \mathrm{~m}-4.0 \mathrm{~m}$ above mean seal level Nwilo (1996).

From a historical perspective, Lagos has always been susceptible to various types of flooding which are well documented from the 1960s onwards. Flooding in Lagos has occurred annually (usually between July and October rainy season) with an increasing intensity and an increased severity of impacts from 1960 onwards.

Lagos is one of the few States in Nigeria with more frequent flooding events. A number of floods have occurred in the State, although keeping track of events in the Nigerian context is challenging due partly to lack of relevant data collection capacities. As a result, data relating to hydrodynamics and historical flooding events are often lacking (Ajibade et al., 2013).

Therefore, flood vulnerability maps need to be created as they provide a basis for the development of flood risk management plans. Reduction of the risk of flooding will depend largely on the amount of information on the flood that is available and the knowledge of the areas that are likely to be affected during a flood event.

\section{Types of Floods}

- Flash Floods: Flash floods occur where the rise in water is either during or within a few hours of rainfall that produces the rise, they occur within small catchments where the response time of the drainage basin is short. Hydrological factors responsible for a flash flood include terrain gradients, soil type, vegetative cover, human habitation, etc.

- River Floods: River floods in contrast to flash floods typically unfold over days, or even months. This is because they occur in large basins involving main stem rivers like the Nile, river Niger or Benue and are usually the result of many individual rainfalls spread out over many days. It is possible to have several flash floods events within a river flood event (Iyiola et al, 2019).

- Coastal Floods: They are floods that normally occur in low-lying part of mangrove and fresh water swamps located along coastal area generated by winds from intense off-shore storms and Tsunamis

- Urban Floods: As the name implies, it takes place in urban areas especially towns located at flat and low-lying terrain especially were drainages are not available or poorly built or have been blocked by disposal municipal waste and eroded soil materials

- Floods arising from non-precipitation events: Apart from floods directly from rainfall, there are many ways in which precipitation can cause floods, perhaps long after it has fallen. When water is impounded by the construction of dams, there is some risk that the dams will fail. Flood can also arise through the melting of snowfall. Deposits of snow and ice on volcanic peaks can melt rapidly during eruptions (Dosewell, 2003).

\section{Problem Definition}

Flooding in Lagos State is a yearly event as a result of climate change, heavy rainfall, topography of the state, urbanisation and population growth of the state which has resulted to loss of lives and properties worth billions of Naira. Governments at all levels had made several attempts to reduce the impacts of flooding in the state and there is no positive result from the effort.

\section{Aim and Objectives of the Study}

The aim of this study is to use remote sensing and GIS techniques to investigate the degree of flood vulnerability in Lagos State. The objectives include:

- Review of different types of flood and identification of factors responsible for coastal flooding in the study area

- Acquisition of spatial and other attribute data

- Identification of different land uses in the study area

- Spatial analyses and production of flood vulnerability maps

\section{Study Area}

The study area for this work covers the entire Lagos State in the south-western geopolitical zone of Nigeria. The state landmass is about 3,557 $\mathrm{Km}^{2}$ of which $22 \%$ are lagoons and creeks. It is bounded on the north and east by Ogun State, in the west by the Republic of Benin and in the south by the Atlantic Ocean. $22 \%$ of its landmass makes up of lagoons and creeks. 


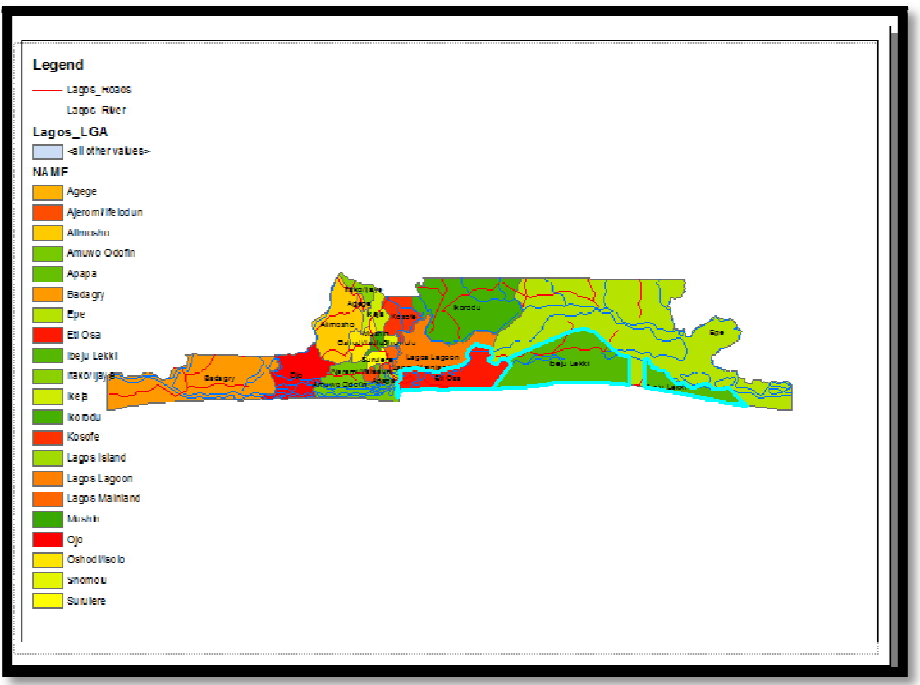

Figure 1: Map of Lagos State

\subsection{Lagos Topography}

Lagos topography can be divided into two main geographical areas: The Island and the Mainland. The Island areas of Lagos are land surrounded by water from creeks and Atlantic Ocean. They are collection of Island separated from each other by lagoons and creeks and separated from the rest of the state mainland. The Islands and the Mainland are connected by bridges (Soladeye and Ajibade, 2014).

Mainland areas of Lagos are non-island areas connected to each other and the rest of the country by land. It is where the huge population of Lagosians live, and most industries are located there.

The topography of both Islands and Mainland areas of Lagos State are dominated by lagoons and sandbars, the terrain is relatively flat on most of the land areas. The drainage system is characterised by a network of lagoons and waterways. The major water bodies are the Yewa and Ogun rivers, Lagos and Lekki lagoons. Others are Ologe Lagoon, river Imede and riverOmu. The drainage system of the state and the terrain pattern which is relatively flat increases the risk of pluvial flooding (flooding as a result of high intensity of rainfall). Likewise, the state bordering the ocean in the south also increases the risk of tidal flood. Lagos State experiences flooding almost every year during raining seasons.

\section{Major Human Activities and Causes of Flooding in Lagos}

The major human activities as identified by Eze et al (2016) in Lagos coastal areas are residency, recreation, industrial, commercial, waste disposal, military and strategic, agriculture, fishing, aquaculture and conservation. The causes of flooding in Lagos include:

- Climate-change-induced short-duration high-intensity or long-duration low-intensity rainfall

- Topography of the state, land use and land cover modifications

- Urbanisation and population growth

- Poor urban planning and environmental management

- Indiscriminate disposal of solid wastes (Nkwunonwo et al, 2016)

\section{Impacts of Flooding in Lagos State}

The impacts of flooding in Lagos Islands and creeks and other parts of Lagos include destruction of beaches, infrastructures like roads, electricity, flooding of houses and disruption of commercial activities, salt water intrusion into the lagoon and other sources of water.

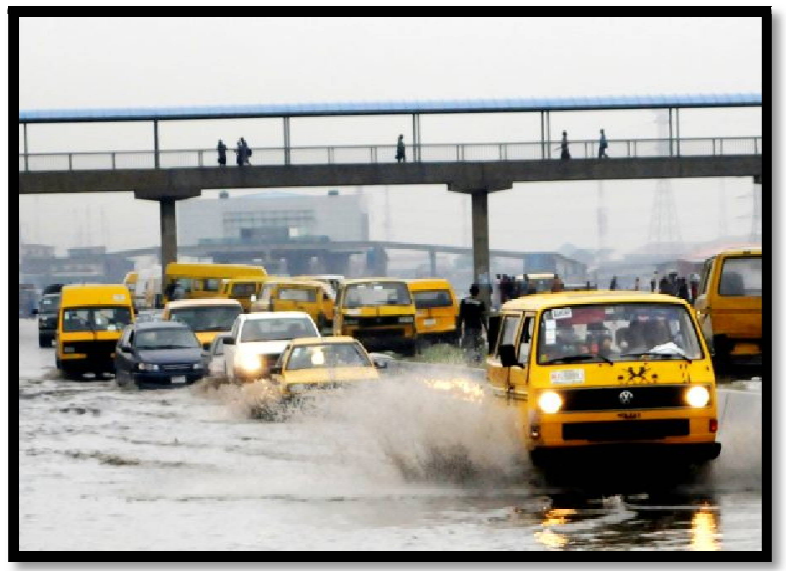

Figure 2: Flooded Road in Lagos 


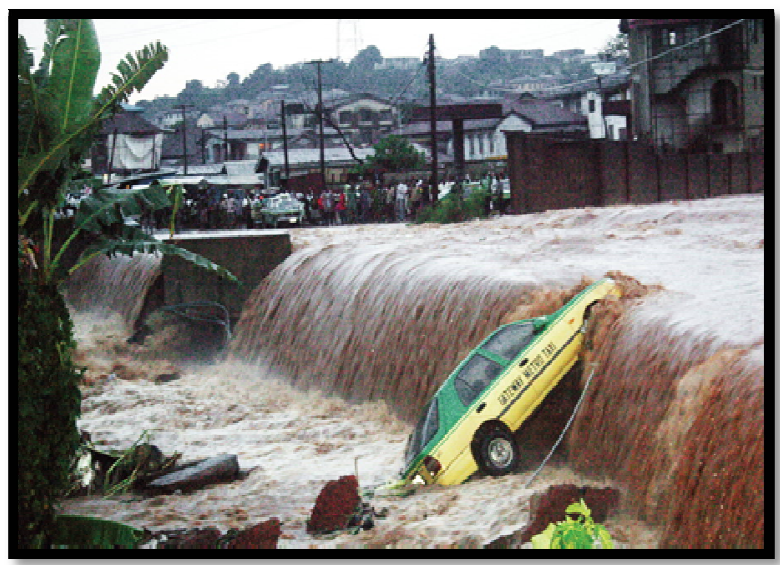

Figure 3: Impact of Flood after Heavy Downpour

\section{Methodology}

This involves methods, rules and procedures to investigate areas vulnerable to flooding in Lagos State.

\subsection{Datasets Required}

- $\quad$ SRTM elevation data (30m Resolution acquired on 11 th February 2000 and published on 23rd September 2014)

- Sentinel-2 image (10 m Resolution for bands 2, 3, 4, and 8 and acquired on 1 stJanuary, 2019)

\subsection{Hardware and Software Required}

- $\quad$ Hp Laptop with 8GB RAM and 500GB Hard disk space

- $\quad$ ArcGIS 10.6

- $\quad$ Earth explorer (www.earthexplorer.usgs.gov)

- $\quad$ Microsoft Word 2010

- $\quad$ Microsoft PowerPoint 2010

\section{Image Downloading and Processing}

\subsection{SRTM Data}

Three tiles $\left(1^{\circ} \times 1^{\circ}\right)$ of one arc-second SRTM (30m resolution) covering the state were downloaded in earth explorer (http://earthexplorer.usgs.gov/). The tiles were mosaicked and spatial analyst tools in ArcGIS 10.6 were used to generate the following products:

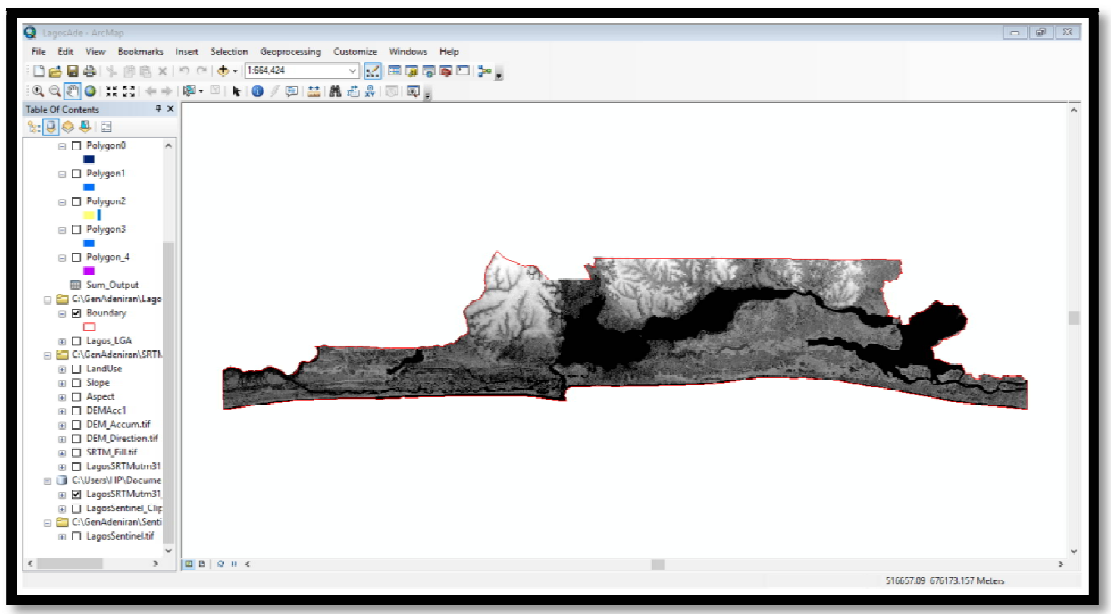

Figure 4: Elevation Data for Lagos State

Flow Direction: One of the keys to deriving hydrologic characteristics of a surface is the ability to determine the direction of flow from every cell in the raster image. Flow direction tool takes a surface as input and outputs raster showing the direction of flow out of each cell.

Hydrologists use flow direction maps to model how surface runoff contributes to flooding. 


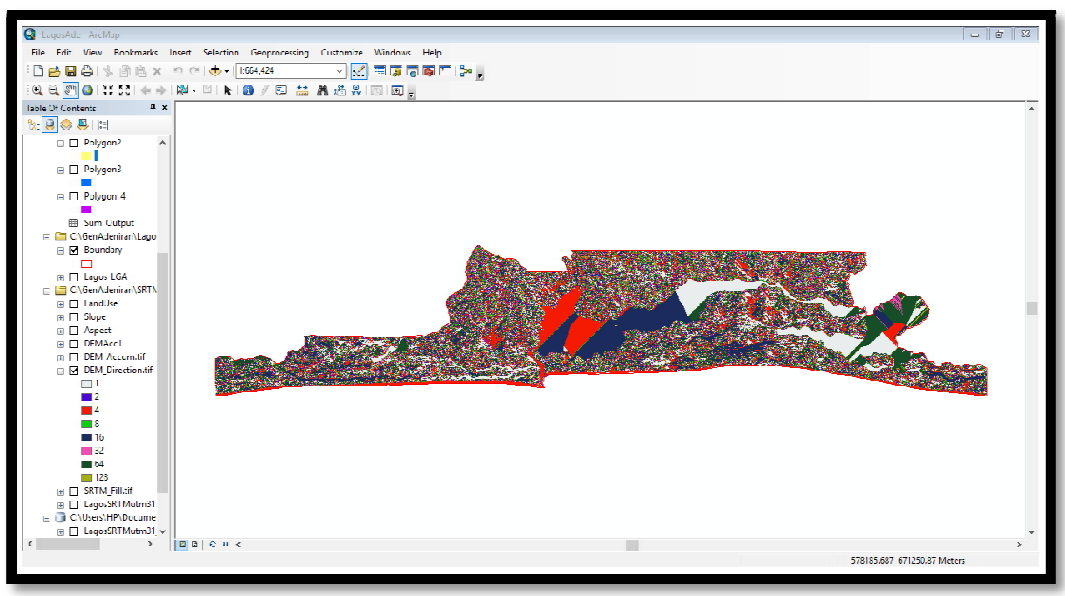

Figure 5: Flow Direction Map

Flow Accumulation: The flow accumulation tool calculates accumulated flow as the weight of all cells flowing into each downslope cell in the output raster. If no weight raster is provided, a weight of 1 is applied to each cell and the value of cells in the output raster is the number of cells that flow into each cell.

River Network: The river network for Lagos State was generated from SRTM data, a river network is composed of the collection of all the paths formed by every tributary of the main river in its drainage basin.

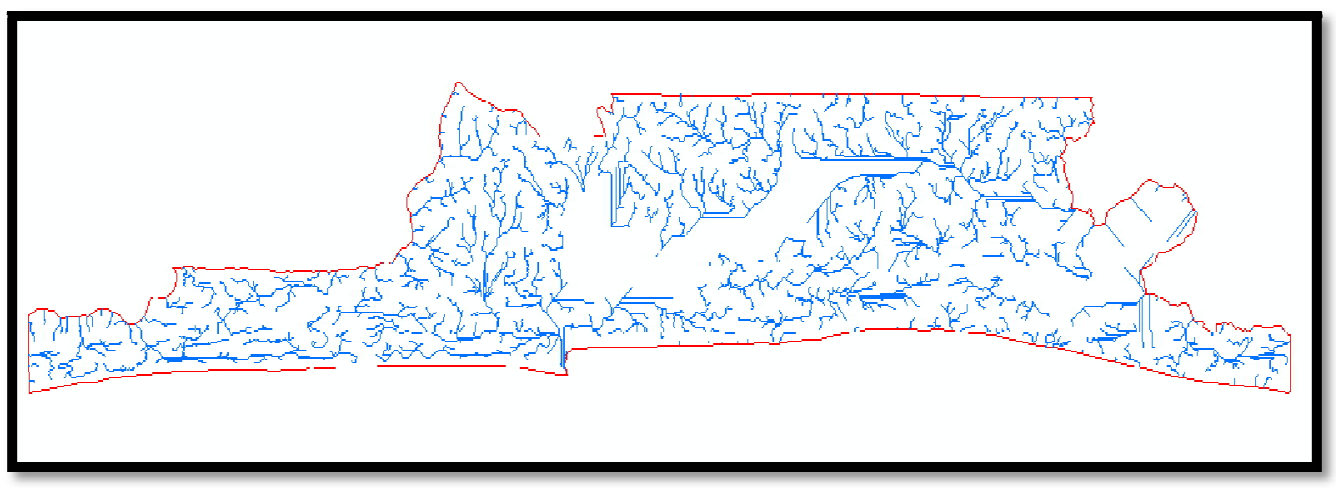

Figure 6: Digital River Network

Slope: Slope is the steepness of the terrain which is very important in GIS operations and environmental modelling. Slope is an important factor in flood modelling, erosion control, engineering projects, etc.

Aspect: Aspect is the direction the slope faces and it is useful for positioning an object where it can receive sufficient sunlight and in agriculture where a particular crop would yield better.

Water level: The height reached by the water in a reservoir, river, dam or storage tank

\subsection{Sentinel-2 Images}

Three image scenes of Sentinel-2 satellite image covering the state were also downloaded in earth explorer (http://earthexplorer.usgs.gov/) and further processed in ArcGIS 10.6.

Supervised image classification was performed on the mosaicked Sentinel-2 by taking training data (samples) of each landuse class and creating a signature file for the study area.

Landuse classification types include:

- Built-up areas

- Bare soil

- Swamp

- Light vegetation

- Water body

Maximum likelihood classification method was used on the raster bands to create a classified raster output showing various landuse types in the study area. 


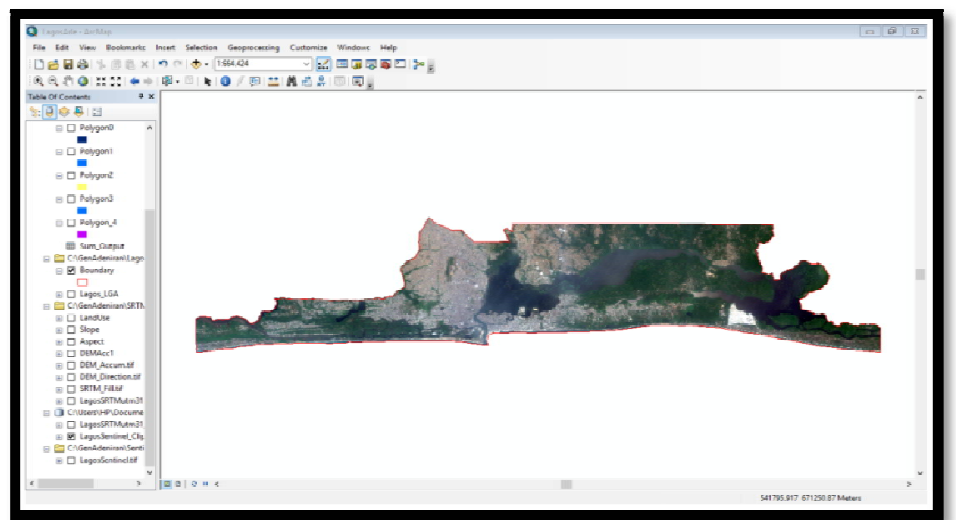

Figure 7: Sentinel-2 Image of Lagos State

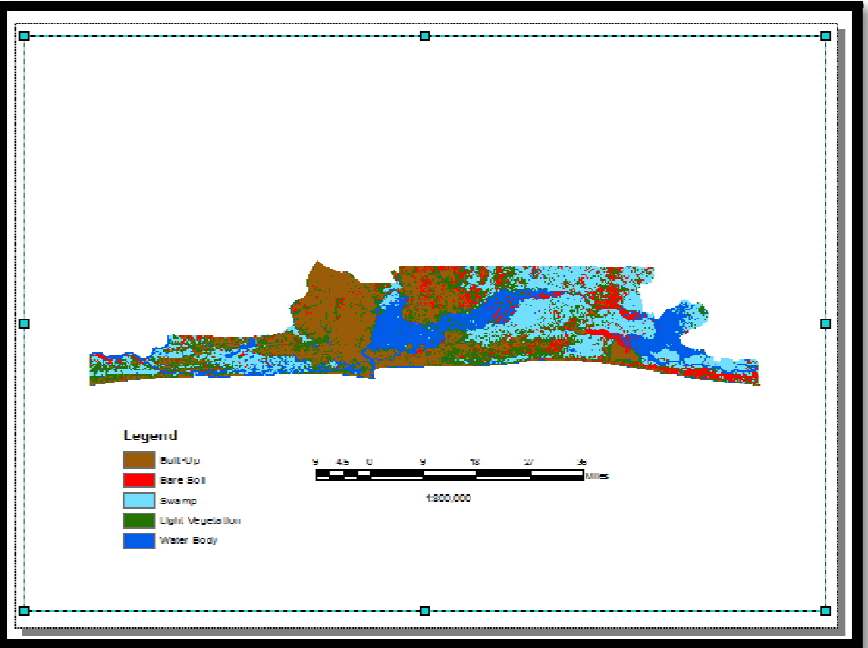

Figure 8: Classified Landuse Image of Lagos State

\begin{tabular}{|c|c|c|c|c|}
\hline S/N & LAND_USE & pixel & Area & Percentage \\
\hline 1 & BUILT-UP & 9032161 & 903216100 & 24.8646515 \\
\hline 2 & BARE SOIL & 3406466 & 340646600 & 9.3776661 \\
\hline 3 & SWAMP & 9089441 & 908944100 & 25.0223377 \\
\hline 4 & LIGHT VEGETATION & 7908571 & 790857100 & 21.7715187 \\
\hline 5 & WATER BODY & 6888668 & 688866800 & 18.963826 \\
\hline
\end{tabular}

Table 1: Area Covered By Each Landuse Type

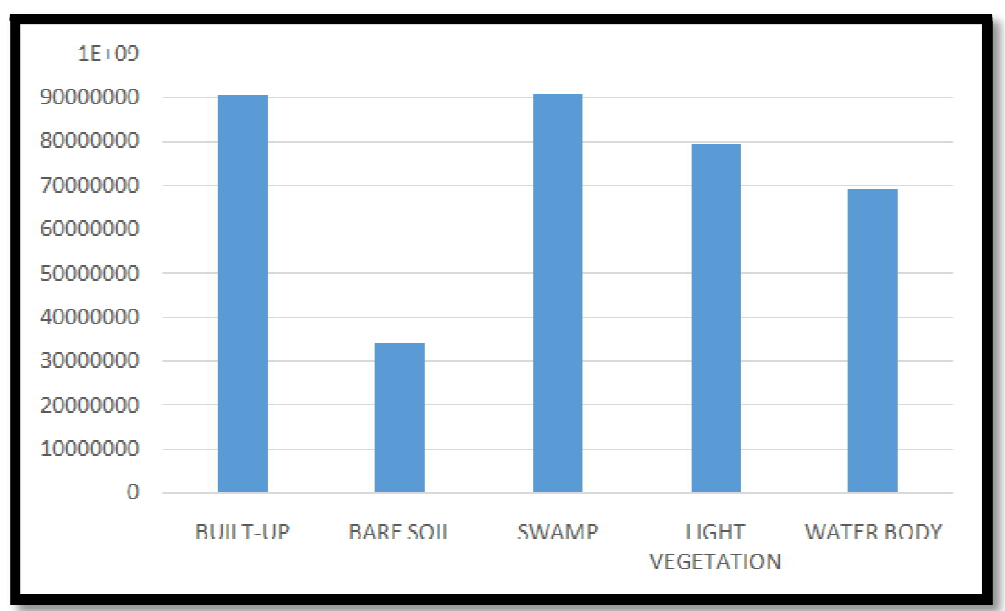

Figure 9: Histogram for Landuse Types in the Study Area

\section{Inundation Map}

Areas inundated for $1 \mathrm{~m}, 2 \mathrm{~m}, 3 \mathrm{~m}$ and $4 \mathrm{~m}$ rise in water level were mapped using elevation data from SRTM. 


\begin{tabular}{|c|c|}
\hline Water Level Rise (m) & AREA (m $\mathbf{~}^{\mathbf{}} \mathbf{~}$ \\
\hline 1 & 804622334.374 \\
\hline 2 & 875166862.717 \\
\hline 3 & 964839876.885 \\
\hline 4 & 157661388.966 \\
\hline
\end{tabular}

Table 2: Inundated Areas

The table shows the portion of the earth that will be inundated as a result of increase in water level

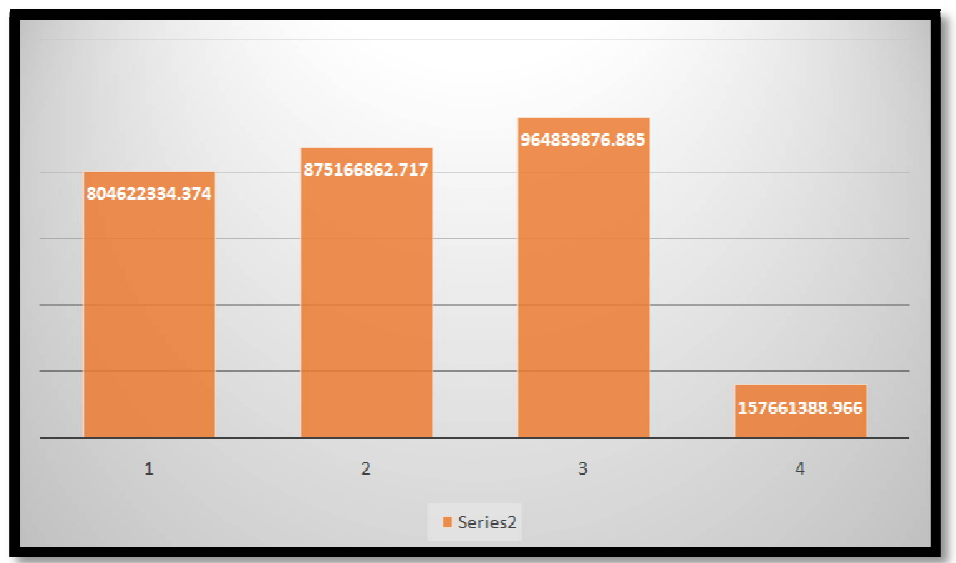

Figure 10: Histogram for Inundated Areas

\section{Vulnerability Mapping}

Areas vulnerable to flooding were mapped from the Sentinel-2 image for both lagoons/creeks and mainland.

\subsection{For Areas Surrounding Lagoons and Creeks}

Areas vulnerable to flooding in Lagos state were mapped and classified as high, moderate and low.

- $\quad$ High vulnerability with DEM heights less than 4

- $\quad$ Moderate vulnerability with DEM height between 4 and 8

- Low vulnerability with DEM height between 8 and 12

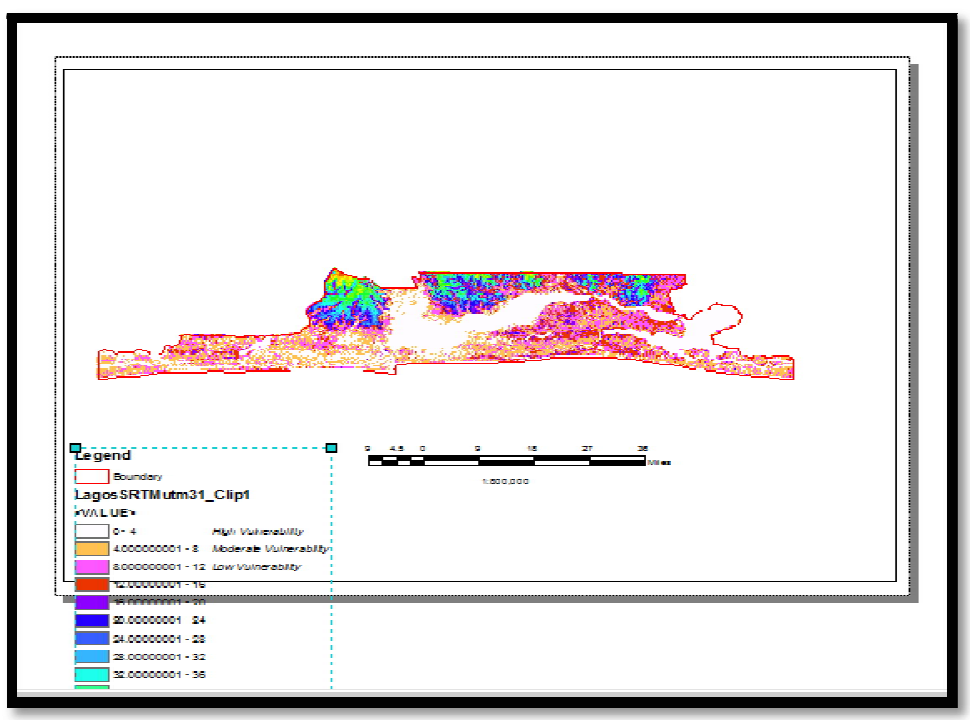

Figure 12: Vulnerability Map for Lagoons and Creeks

\subsection{Vulnerability Mapping in the Mainland}

The rivers were buffered and classified as follows:

- High Vulnerability (50m from river bank)

- Moderate Vulnerability (50m - 100m)

- Low Vulnerability (100m - 150m) 


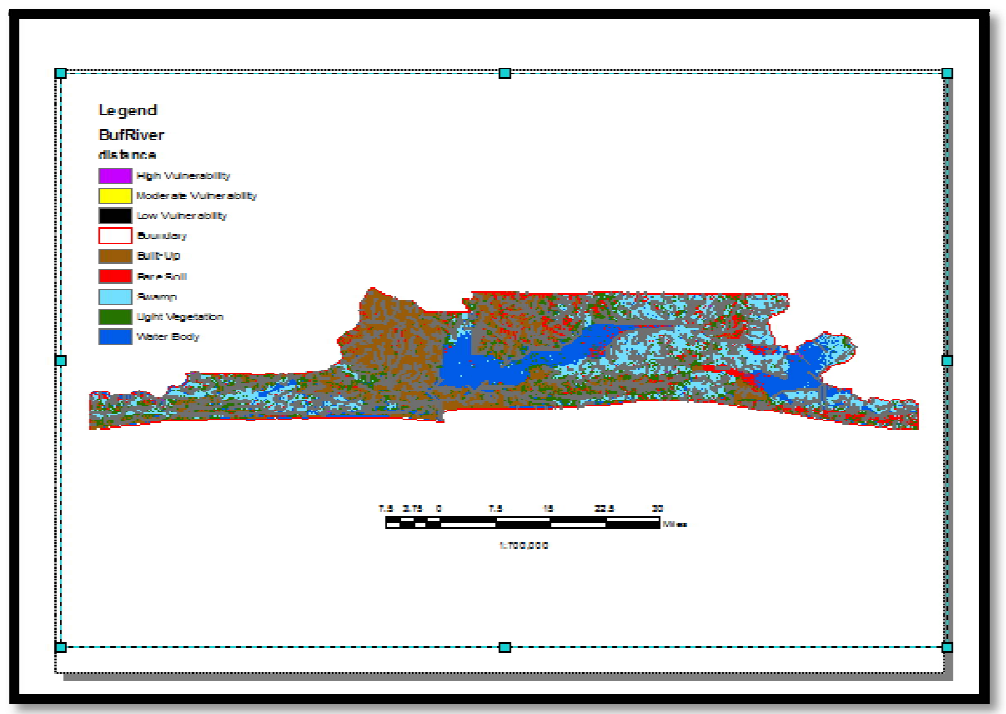

Figure 11: Vulnerability Map for Mainland

\section{Conclusion}

Products generated from this study show that there are human activities (Residential, commercial, etc.) around lagoons/creeks and mainland which contribute to flooding in Lagos state. More than 50\% of Lagos state land are water bodies (lagoons, creeks or rivers). The classified image shows various landuse types while the vulnerability maps are useful to serve as warning to people living in areas vulnerable to flooding.

\section{Recommendations}

The following recommendations are hereby made:

- People living or doing business in highly vulnerable areas of the state should be evacuated and resettled in a better environment to avoid loss of life and properties

- Government should embark of flood mapping and the results should be used by urban planning authority to give approval for development permit

- Indiscriminate dumping of refuse on waterways, open spaces, uncompleted buildings and canals should be discouraged to avoid flooding

\section{References}

i. Ajibade, I., McBean, G., and Bezner-Kerr, R (2013).: Urban flooding inLagos, Nigeria: patterns of vulnerability and resilience among women, Global Environ. Change, 23, 1714-1725

ii. Antonella N, Gian Domenico F, Caterina C, Pierfabrizio P and Francesca M (2018). Coastal Flooding: Damage Classification and Case Studies in Calabria, Italy. WIT Transactions on Engineering Sciences, Vol 121, doi:10.2495/RISK180081, ISSN 1743-3533 (on-line)

iii. Dosewell C. A (2003): Flooding. Elsevier Science ltd

iv. Eze M. U, Alozie G. C and Nwogu N (2016): Coastal erosion and tourism infrastructure in Lagos State. International Journal of Advanced Research in Social Sciences, Environmental Studies and Technology .hard print: 2536-6505 Online: 2536-6513

v. Iyiola O. F, Effiong E and Ajani A (2019): Geospatial Mapping and Assessment of Areas Vulnerable to Flooding in Ibadan, Oyo State. Being a paper presented during the Annual General Meeting (AGM) of the Nigerian Institution of Surveyors (NIS) held between Monday 17th and Friday 21st June, 2019 at Awka, Anambra State, Nigeria.

vi. Nkwunonwo U. C, Whitworth M and Baily B (2016): A review and Critical analysis of the efforts towards urban flood risks management in Lagos region of Nigeria. National Hazard Earth System

vii. Nwilo P. C (1996): Managing the impacts of storm surges on Victoria Island, Lagos, Nigeria. Proceedings of the conference on Destructive Water: Water-Caused Natural Disasters, their Abatement and Control held at Anaheim, California, June 1996. IAHS Pub. No $\quad 239,1997$

viii. Soladoye, O. and Soladoye, O. (2014): 'A Groundwater Quality Study of Lagos State, Nigeria' International Journal of Applied Science and Technology l.4 (4) Retrieved from: http://www.ijastnet.com/journals/Vol_4_No_4_July_2019/32.pdf 